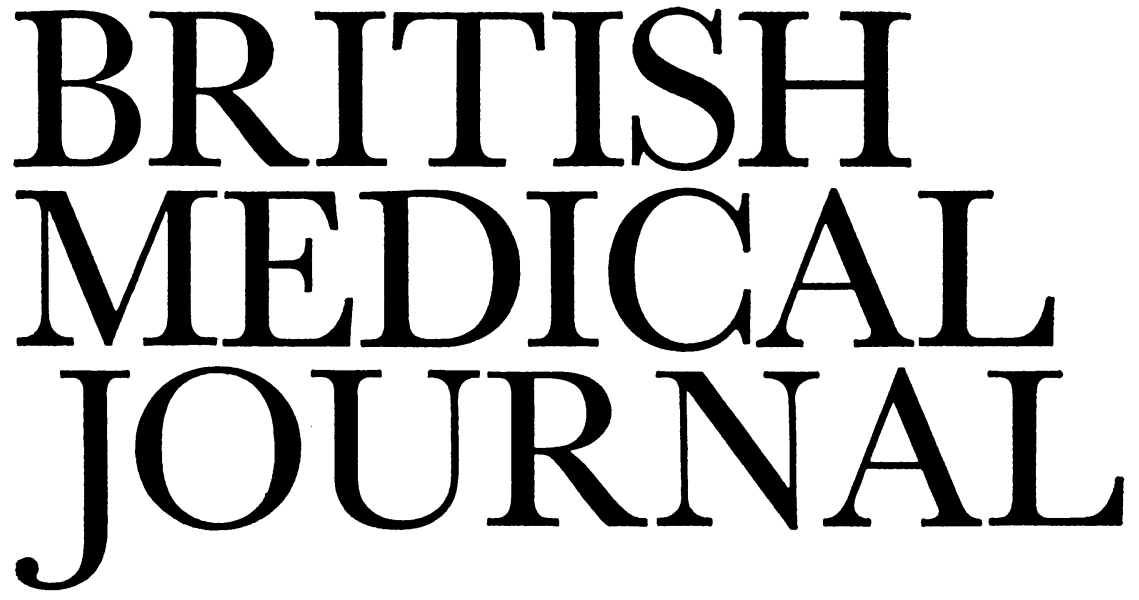

LONDON SATURDAY 17 APRIL 1971

\title{
Shut Away
}

The tragic events at Farleigh Hospital, in Somerset, that led to the conviction of three male nurses, for ill treatment of patients are now reported upon by the committee of inquiry set up by the Secretary of State for Social Services. In addition to making detailed suggestions for improving things locally the committee recommends that "a Health Commissioner, given the widest possible powers, should be appointed urgently to meet public anxiety about the investigation of complaints in the health service." This suggestion is popular at present for several reasons. Not the least of them is that it is almost as easy to fulfil as to make. But whether it offers a realistic preventive against a repetition of such disasters is another matter.

The background to the tragedy at Farleigh Hospital, in the course of which a patient died, is clearly set out in the report. The scene is all too familiar. The main buildings date from 1838. The patients comprise about 270 boys and men who are either mentally handicapped or severely mentally handicapped. During the time in question it was "grossly understaffed" by nurses. Long-standing differences existed between the then medical superintendent and the hospital management committee, described as "a constant tug-ofwar". Psychiatric leadership, we are told, was almost nonexistent, and a "grave responsibility" must rest with the regional hospital board. The chief nursing officer, who is acknowledged to have been overworked, is criticized for appointing two of the men subsequently convicted, but "he was hard pressed for staff and was doing his best to remedy the situation."

After inquring carefully into the administration of the hospital and the conditions there the committee has made some recommendations that will no doubt help to prevent a recurrence of what was nothing less than an appalling situation. But in addition it recommends changes of a more farreaching character, and these deserve a more thorough airing than in the present climate of opinion they seem likely to get. To help our readers understand one view-and it is a view that is too little heard-we reprint at page 180 a petition sent by the nursing staff at Farleigh Hospital to the Secretary of State for Social Services in April 1970-sent, that is, just after the last trials of the nurses ended and before the committee of inquiry was appointed. The difficulties of obtaining staff for mental deficiency hospitals-indeed for all mental hospitals - are too little appreciated in the community generally. The first to criticize when something goes wrong would be the last to work in these institutions.

As the report rightly says, the nursing of mentally defective patients calls for a high degree of skill, compassion, and patience. It acknowledges that Farleigh Hospital was grossly understaffed. Yet it can make this extraordinary comment: "Fortunately, there is a large number of men and women with these qualities who are devoted to this kind of work." Whatever the epithet "large" is supposed to mean in this context, the fact is that there are nothing like enough. Nor will there be until conditions are made vastly more attractive for them.

It is against this background that the recommendation by the committee that "a Salmon nursing staff structure should be introduced early" seems odd, especially at a time when the principles of the structure itself are being widely questioned. Again, what can the appointment of a Health Commissioner do-except perhaps "meet public anxiety"? This is a politician's way of remedying defects. If something goes wrong, appoint an official. But it will not heal the wound itself, and that is public indifference. Not only does the community care too little about these patients: even their relations pay scant attention to them. For most of the patients at Farleigh Hospital and others like it the hospital is virtually their only home, yet "Few of them ever receive visits from relatives or friends." It is tempting to shut away a mentally defective person, forget about him, and appoint a Health Commissioner to see he is all right. But is that all we can expect from the community?

1 Committee of Inquiry, Report of the Farleigh Hospital, Cmnd. 4557. London, H.M.S.O.. 1971 (25p net).

\section{No Man an Island}

The isolation of insulin fifty years ago was instantly seen to be what posterity has affirmed-one of the great landmarks in the history of medicine. Sherrington, who was then president of the Royal Society, spoke of "the deserved success of a bold attack conducted with conviction and determination, and carried through in the face of formidable ex- 
perimental difficulties."' Some quarter-century later Dale ${ }^{2}$ recalled that in consequence of Banting and Best's achievement "from that point onwards the atmosphere of therapeutic research on endocrine organs and functions became one of renewed optimism and enterprise." Of the chief players in this drama only Professor Charles Best survives, and happily he is taking part in the jubilee celebrations of the event beginning in Great Britain next week.

It is a truism that great scientific discoveries are not suddenly snatched out of the sky. Much work leads up to them, often the work of people who for one reason or another fail to share in the final achievement. And it is no disparagement of the Canadians' work to acknowledge that it too had its predecessors. Sherrington ${ }^{1}$ himself drew attention to this in an apt quotation from Pasteur: "To have the fruit there must have been cultivation of the tree." Attempts to isolate a substance from the pancreas that would be a remedy for diabetes mellitus first occupied the attention of research workers in the first decade of the twentieth century. That story as well as its crowning conclusion has recently been the subject of a perceptive review by Professor Ian Murray, ${ }^{3}$ timed to celebrate the centenary of Langerhans's description in 1869 of the islets that bear his name.

At some point before the first world war the distinguished Rumanian physiologist N. C. Paulesco began work on the isolation of the antidiabetic principle from the pancreas, but his research was tragically interrupted, Murray relates, when enemy troops occupied Bucharest in 1916. Thus it was not until 1921 that he was able to publish his results and so provide convincing proof of the hypoglycaemic properties in the dog of a pancreatic extract that he had obtained. Because Paulesco's work was completed-and by a narrow margin published - before that of the Toronto team, medical circles in Rumania felt surprise and disappointment ${ }^{3}$ at his not having any share in the Nobel prize that was awarded in 1923 -but that award caused heartburning in other places as well. What had also occasioned some surprise, ${ }^{5}$ as Professor E. Martin, of Geneva, has now noted, was the brief and mistaken impression of Paulesco's work given in the original report by Banting and Best, ${ }^{6}$ an impression wholly at variance with the generosity and goodwill of these authors.

Now an interesting footnote to history has appeared from Best's pen in the Swiss periodical Schweizerische medizinische Wochenschrift, for it is this odd discrepancy that Best has cleared up in a letter published by Professor Martin. In reply to an inquiry about this matter from Professor Pavel, of Bucharest, Best wrote as follows: "I regret very much that there was an error in our translation of Professor Paulesco's article. I cannot recollect after this length of time, exactly what happened. As it was almost fifty years ago I do not remember whether we relied on our own poor French or whether we had a translation made." Anyone who has tried to keep up-to-date in the world's literature on his subject will feel the keenest sympathy for Professor Best and acknowledge that such scrupulous amends are rarely made.

Banting was an inexperienced part-time demonstrator in physiology and Best a medical student when they achieved their great work with the assistance and in the laboratory of Professor J. J. R. Macleod at Toronto. Working at the same time in the department was J. B. Collip, a biochemist from Edmonton, on a Rockefeller fellowship, and it was he who succeeded in preparing sufficiently refined extracts of insulin for clinical use. The first patient, a boy of 12 , was treated in January 1922, with encouraging results. Largescale manufacture of a pure preparation for the treatment of patients was now an obvious goal, and the Eli Lilly Company, brought in at the invitation of the Toronto team, turned its full research capacity on to the project. Patent rights were gifted to Toronto University and in Great Britain assigned to the Medical Research Council.

How could any award to these resourceful pioneers, whose work had brought such inestimable benefit to humanity, be apportioned in a manner that justly acknowledged the drive, insight, and originality of each? In the upshot the Nobel prize was divided between Banting and Macleod. Dissatisfied with this judgement, Banting gave half his share of the prize to Best and Macleod then gave half his to Collip. But the team dissolved: "The clash of personalities of men working at an extreme pitch of exhaustion and the resulting split and break-up of this world-famous group must go down as one of the most unfortunate tragedies in the annals of medical research.""

Since those heroic days we have witnessed the determination of the structure of the insulin molecule by F. Sanger, who received a Nobel prize in 1958 for his work, and the elucidation of the crystalline structure by Dorothy Hodgkin, who had earlier, in 1964, won a Nobel prize for her crystallographic studies of large molecules. The biosynthesis of this hormone in the body is gradually being worked out and its mode of action elucidated. But to Banting and Best and their collaborators will always remain the honour of having enabled effective, life-saving treatment to be offered to millions of sufferers from a disease that for many of them was inevitably fatal.

${ }^{1}$ British Medical fournal, 1922, 2, 1139.

2 Dale, Sir H. H., British Medical fournal, 1950, $1,1$.

3 Murray, I., Scottish Medical fournal, 1969, 14, 286

4 Paulesco, N. C., Archives Internationales de Physiologie, 1921, 17, 85

5 Martin, E., Schweizerische medizinische Wochenschrift, 1971, 101, 164

6 Banting, F. G., and Best, C. H., fournal of Laboratory and Clinical Medicine, 1922, 7, 251 .

7 Noble, R. L., Canadian Medical Association Fournal, 1965, 93, 1356.

\section{Mind and Childbirth}

The Third International Congress of Psychosomatic Medicine in Obstetrics and Gynaecology, held in London, came to an end on 2 April after four full days. It attracted some 800 people from 50 different countries, and among them were gynaecologists, psychiatrists, psychologists, general practitioners, midwives, physiotherapists, social workers, and others interested in the field. The scope of the congress was enormous. Some 250 papers were read, covering population problems, preparation for labour, sex education, teenage pregnancy, the unmarried mother, puberty and adolescence, sex identity, sexual response, psychological and psychiatric problems of pregnancy, the family and its relationships, the role of the father, pelvic pain, the emotional problems of pelvic surgery in the female, hyperemesis gravidarum, toxaemia of pregnancy, habitual abortion, premature labour, family planning, the gynaecologist and the psychosomatic patient, frigidity, stillbirth, the management of labour, therapeutic abortion, menstrual disorders, the puerperium, lactation, mother-infant relationships, doctor-patient relationships, puerperal depression, the menopause, and the postmenopause. The list should convince the sceptical about the range of modern obstetrics and gynaecology, and ought to convince the doubters who wonder what psychosomatic medicine is about. For few would deny the interactions of psyche and soma in those subjects which were discussed. 